Supporting Information

\title{
Critical membrane concentration and mass-balance model to identify baseline cytotoxicity of hydrophobic and ionizable organic chemicals in mammalian cell lines
}

Jungeun Lee, ${ }^{\dagger}$ Georg Braun, ${ }^{\dagger}$ Luise Henneberger, ${ }^{\dagger}$ Maria König, ${ }^{\dagger}$ Rita Schlichting ${ }^{\dagger}$, Stefan Scholz, ${ }^{\S}$ Beate I. Escher, ${ }^{\dagger *}$

†Department of Cell Toxicology, Helmholtz Centre for Environmental Research - UFZ, Permoserstr. 15, DE04318 Leipzig, Germany,

${ }^{\S}$ Department of Bioanalytical Toxicology, Helmholtz Centre for Environmental Research - UFZ, Permoserstr. 15, DE-04318 Leipzig, Germany,

*Environmental Toxicology, Center for Applied Geoscience, Eberhard Karls University Tübingen, Scharrenbergstr. 94-96, DE-72076 Tübingen, Germany 


\section{Table of Content}

Figure S1. Workflow of this study.

Table S1. Number of available partition constants of a total of 392 chemicals used for model validation ......

Table S2. Environmentally relevant chemicals, their speciation at $\mathrm{pH} 7.4$, liposome-water partition constant at $\mathrm{pH}$ 7.4, protein binding constants at $\mathrm{pH} 7.4$, and experimental cytotoxicity $\mathrm{IC}_{10}$ - see Supporting Information excel file.

Table S3. Experimental physicochemical parameters for organic acids; partitioning constants between BSA and water $\left(\mathrm{D}_{\mathrm{BSA} / \mathrm{w}}\left(\mathrm{pH}\right.\right.$ 7.4) $\left.\left(\mathrm{L}_{\mathrm{w}} / \mathrm{LBSA}_{\mathrm{BS}}\right)\right)$, liposomes and water $\left(\mathrm{D}_{\mathrm{lip} / \mathrm{w}}\left(\mathrm{pH}\right.\right.$ 7.4) $\left.\left(\mathrm{L}_{\mathrm{w}} / \mathrm{Llip}_{\mathrm{lip}}\right)\right)$, structural proteins and water $\left(\mathrm{D}_{\mathrm{SP} / \mathrm{w}}(\mathrm{pH} 7.4)\left(\mathrm{L}_{\mathrm{w}} / \mathrm{kgSP}\right)\right),{ }^{1}$ medium and water $\left(\mathrm{D}_{\text {medium } / \mathrm{w}}(\mathrm{pH} 7.4)\left(\mathrm{L}_{\mathrm{w}} / \mathrm{L}_{\text {medium }}\right)\right)$, and cells and water $\left(\mathrm{D}_{\text {cell }} / \mathrm{w}(\mathrm{pH} 7.4)\right.$ $\left.\left(\mathrm{L}_{\mathrm{w}} / \mathrm{L}_{\mathrm{cell}}\right)\right)^{2}$

Table S4. Hydrophobic chemicals tested in the current study and their experimental cytotoxicity $\mathrm{IC}_{10}$ and $\mathrm{EC}_{10}$ for activation of the specific effect (reporter gene activation). - see Supporting Information excel file.

Figure S2. Relationship between liposome-water partitioning $\mathrm{D}_{\mathrm{lip} / \mathrm{w}}(\mathrm{pH}$ 7.4) and protein-water partitioning $\mathrm{D}_{\mathrm{BSA} / \mathrm{w}}(\mathrm{pH} 7.4)$ of organic acids

Text S1. Additional considerations for organic acids

Figure S3. Simplified model for organic acids $\left(1.6<\log \mathrm{D}_{\mathrm{lip} / \mathrm{w}}(\mathrm{pH} 7.4)<4.9\right)$ with mean values of experimental $\mathrm{D}_{\text {cell } / \mathrm{w}}\left(\mathrm{pH}\right.$ 7.4) $\left(\mathrm{L}_{\mathrm{w}} / \mathrm{L}_{\text {cell }}\right), \mathrm{D}_{\text {medium } / \mathrm{w}}(\mathrm{pH} 7.4)\left(\mathrm{L}_{\mathrm{w}} / \mathrm{L}_{\text {medium }}\right){ }^{7}$ and $\mathrm{D}_{\mathrm{sP} / \mathrm{w}}(\mathrm{pH} 7.4)\left(\mathrm{L}_{\mathrm{w}} / \mathrm{kg}_{\mathrm{SP}}\right)($ Table S3)..... 5

Figure S4. Comparison of the prediction using the mass balance model (MBM) for baseline toxicity with the previously published baseline toxicity QSAR $\log \left(1 / \mathrm{IC}_{10}\right)-\log \mathrm{K}_{\mathrm{lip} / \mathrm{w}}{ }^{8}$ for $(\mathrm{A}) \mathrm{AREc} 32$, (B) AhR CALUX, and (C) PPAR $\gamma$-BLA.

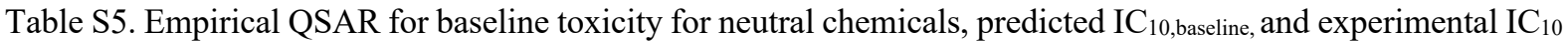
as well as toxic ratios TR. - see Supporting Information excel file.

Table S6. Empirical QSAR for baseline toxicity for charged chemicals, predicted IC 10 ,baseline, and experimental $\mathrm{IC}_{10}$ as well as toxic ratios TR. - see Supporting Information excel file. 


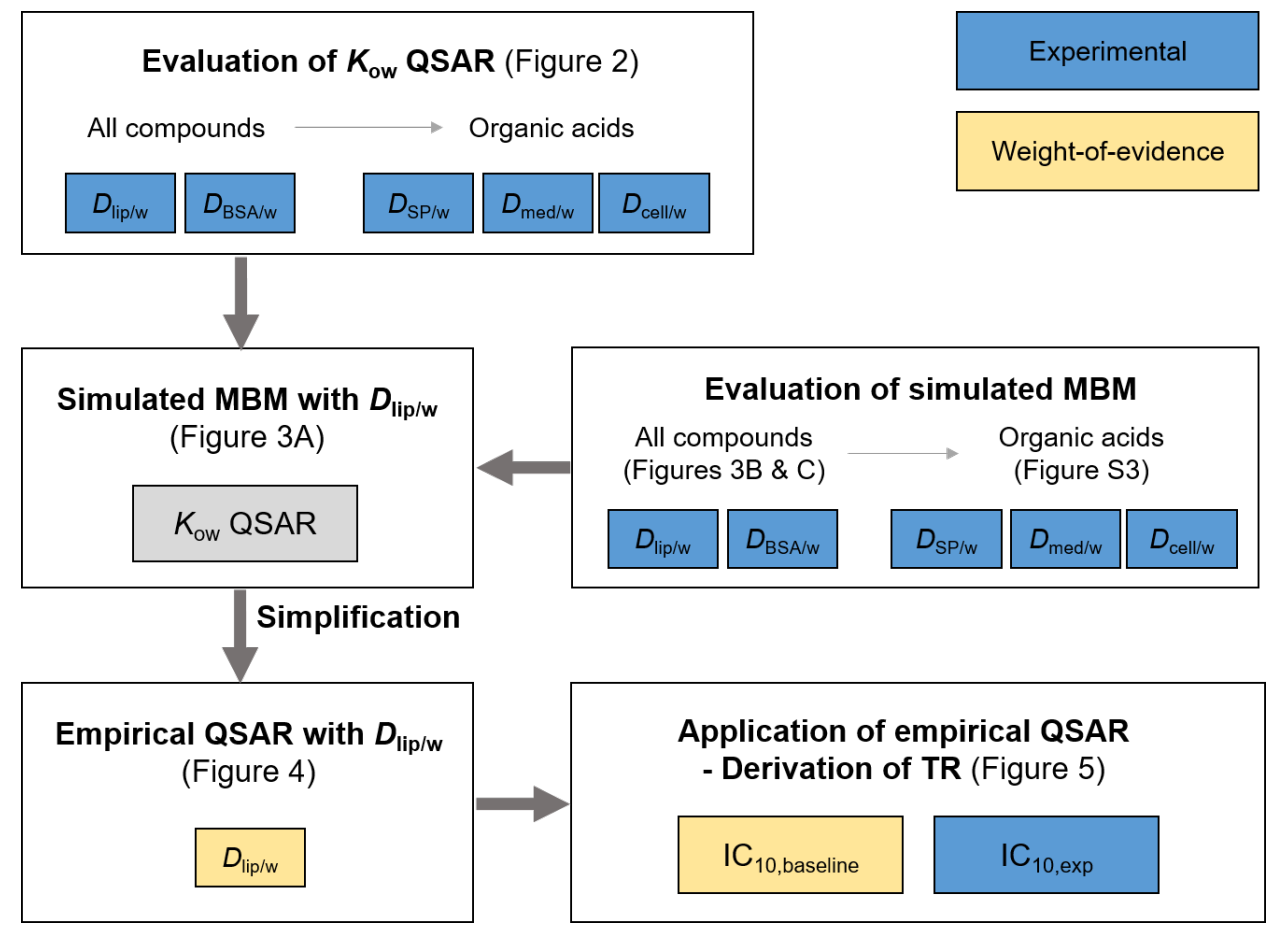

Figure S1. Workflow of this study.

Table S1. Number of available partition constants of a total of 392 chemicals used for model validation (chemicals with, both, experimentally determined distribution ratios between liposomes and water $\left(\mathrm{D}_{\text {lip/w) }}\right.$ ), and bovine serum albumin (BSA) and water $\left(\mathrm{D}_{B S A / w)}\right)$ ) and for model application (chemicals with either experimental or predicted $\mathrm{D}_{\text {lip/w, no }} \mathrm{D}_{B S A / w}$ required). The group of ionizable organic compounds (IOC) was split into those that form cations or multiple ionizable chemicals and those that form anions.

\begin{tabular}{lccccc} 
Number of available data $\rightarrow$ & $D_{\text {lip/w }}$ and $D_{\mathrm{BSA} / \mathrm{w}}$ & & \multicolumn{3}{c}{$D_{\mathrm{lip} / \mathrm{w}}$} \\
\cline { 2 - 2 } \cline { 5 - 5 }$\downarrow$ Chemical species & Experimental & & Experimental & Predicted & Total \\
Neutral & 18 & & 59 & 194 & 253 \\
IOCs: cationic/multiprotic & 6 & 16 & 45 & 61 \\
IOCs: anionic & 14 & & 25 & 53 & 78
\end{tabular}


Table S2. Environmentally relevant chemicals, their speciation at $\mathrm{pH}$ 7.4, liposome-water partition constant at pH 7.4, protein binding constants at $\mathrm{pH} 7.4$, and experimental cytotoxicity $I_{10}$ - see Supporting Information excel file.

Table S3. Experimental physicochemical parameters for organic acids; partitioning constants between BSA

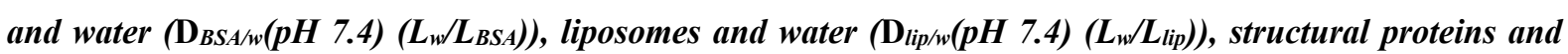
water (DSP/w $\left(p H\right.$ 7.4) $\left.\left(L_{w} / k_{S P P}\right)\right),{ }^{1}$ medium and water $\left(\mathrm{D}_{\text {medium/w }}\left(\mathrm{pH}\right.\right.$ 7.4) $\left.\left(\mathrm{L}_{w} / \mathrm{L}_{\text {medium }}\right)\right)$, and cells and water $\left(\mathrm{D}_{\text {cell/w}}\left(\mathrm{pH}\right.\right.$ 7.4) $\left(\mathrm{L}_{w} / \mathrm{L}_{\text {celll)}){ }^{2}}{ }^{2}\right.$

Table S4. Hydrophobic chemicals tested in the current study and their experimental cytotoxicity $I C_{10}$ and $E C_{10}$ for activation of the specific effect (reporter gene activation). - see Supporting Information excel file.

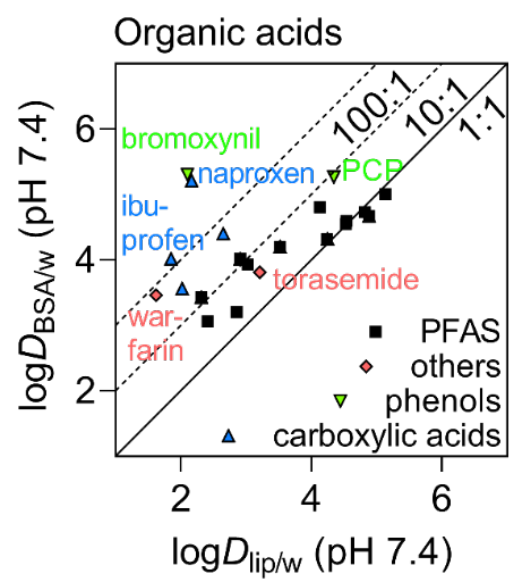

Figure S2. Relationship between liposome-water partitioning $\mathrm{D}_{l i p / w}(\mathrm{pH}$ 7.4) and protein-water partitioning $\mathrm{D}_{B S A / w}(\mathrm{pH}$ 7.4) of organic acids.

Data from Table S1 and literature. ${ }^{3-6}$ PFAS $=$ Perfluorinated Substances, PCP = Pentachlorophenol.

Text S1. Additional considerations for organic acids

The experimental $D_{\text {cell } / \mathrm{w}}(\mathrm{pH} 7.4)\left(\mathrm{L}_{\mathrm{w}} / \mathrm{L}_{\text {cell }}\right)$ and $D_{\text {medium } / \mathrm{w}}\left(\mathrm{pH} \text { 7.4) }\left(\mathrm{L}_{\mathrm{w}} / \mathrm{L}_{\text {medium }}\right)\right)^{7}$ seem to be constant independently of $D_{\mathrm{lip} / \mathrm{w}}(\mathrm{pH} 7.4)$ among the different organic anions (Figure $2 \mathrm{C}$ in main manuscript). Therefore, for organic acids, we used a mean $\log D_{\text {cell } / \mathrm{w}}(\mathrm{pH} 7.4)$ of $1.34(\mathrm{n}=7, \mathrm{SD}=0.22, \mathrm{CV}=16 \%)$ for all cell lines and a $\log D_{\text {medium } / \mathrm{w}}(\mathrm{pH}$ 7.4) of $0.68(\mathrm{n}=7, \mathrm{SD}=0.33, \mathrm{CV}=48 \%)$ for AREc32 and AhR-CALUX and of $0.49(\mathrm{n}=7, \mathrm{SD}=0.28, \mathrm{CV}=$ $57 \%$ ) for PPAR $\gamma$-BLA (Table S3), which are the dotted lines in Figure $2 \mathrm{C}$ in main manuscript, as direct input parameter in eqs. 3 and 4 . We used a mean value of $\log D_{\mathrm{SP} / \mathrm{w}}(\mathrm{pH} 7.4)$ of $1.89(\mathrm{n}=3, \mathrm{SD}=0.62, \mathrm{CV}=33 \%$, Table

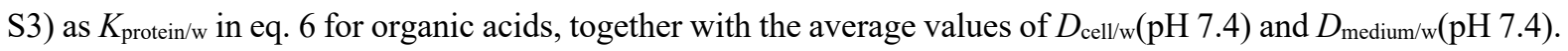

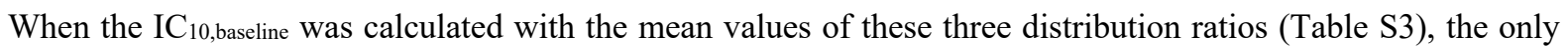
variable descriptor was $D_{\operatorname{lip} / \mathrm{w}}(\mathrm{pH}$ 7.4). The short lines in Figure $\mathrm{S} 3$ refer to this anion-specific version of the MBM, which is only valid in the range of $1.6<\log D \operatorname{lip} / \mathrm{w}(\mathrm{pH} 7.4)<4.9$, because the chemicals included in the calculation 
of mean values covered only this range (Table $\mathrm{S} 3$ ). This prediction of $\mathrm{IC}_{10}$,baseline aligns remarkably well with the MBM simulation that uses eq. 12 as input for protein binding for AREc32 and AhR-CALUX, while the anionspecific models do not correspond to each other for $\log D_{\operatorname{lip} / \mathrm{w}}(\mathrm{pH} 7.4)>3$ for PPAR $\gamma$-BLA possibly due to the higher lipid contents in the cells.
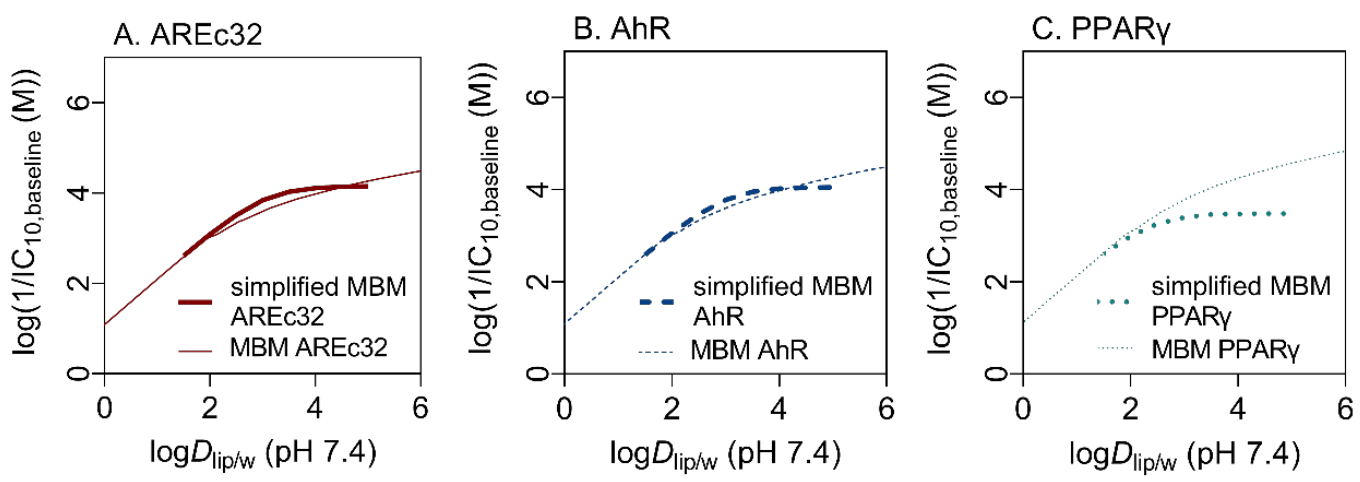

Figure S3. Simplified model for organic acids $\left(1.6<\log \mathrm{D}_{i p / w}(\mathrm{pH} 7.4)<4.9\right)$ with mean values of experimental

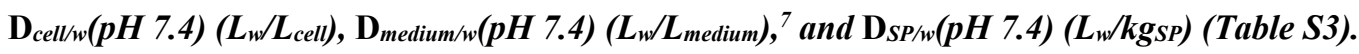
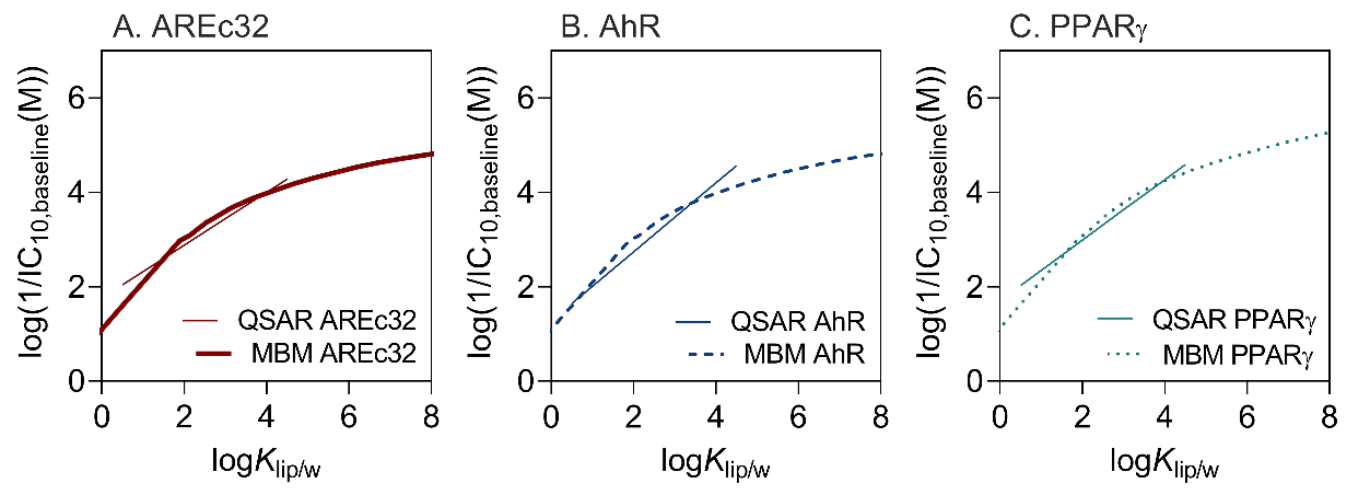

Figure S4. Comparison of the prediction using the mass balance model (MBM) for baseline toxicity with the previously published baseline toxicity $Q S A R \log \left(1 / I C_{10}\right)-\log \mathrm{K}_{l i p / w}{ }^{8}$ for $(A) A R E c 32,(B) A h R C A L U X$, and $(C)$ $P P A R \gamma-B L A$. 
Table S5. Empirical QSAR for baseline toxicity for neutral chemicals, predicted IC 10, baseline, and experimental IC10 as well as toxic ratios TR. - see Supporting Information excel file.

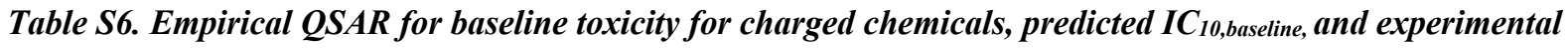
$I_{10}$ as well as toxic ratios TR. - see Supporting Information excel file. 


\section{REFERENCES}

(1) Henneberger, L., Goss, K. U., and Endo, S. (2016) Partitioning of Organic Ions to Muscle Protein: Experimental Data, Modeling, and Implications for in Vivo Distribution of Organic Ions. Environ. Sci. Technol. 50, 7029-7036.

(2) Henneberger, L., Mühlenbrink, M., Heinrich, D., Teixeira, A., Nicol, B., and Escher , B. I. (2020) Experimental Validation of Mass Balance Models for in vitro Cell-based Bioassays. Environ. Sci. Technol. 54, 1120-1127.

(3) Bittermann, K., Spycher, S., and Goss, K. U. (2016) Comparison of different models predicting the phospholipid-membrane water partition coefficients of charged compounds. Chemosphere 144, 382-391.

(4) Henneberger, L., Goss, K. U., and Endo, S. (2016) Equilibrium Sorption of Structurally Diverse Organic Ions to Bovine Serum Albumin. Environ. Sci. Technol. 50, 5119-5126.

(5) Allendorf, F., Berger, U., Goss, K. U., and Ulrich, N. (2019) Partition coefficients of four perfluoroalkyl acid alternatives between bovine serum albumin (BSA) and water in comparison to ten classical perfluoroalkyl acids. Environ. Sci. Process. Impacts 21, 1852-1863.

(6) Ebert, A., Allendorf, F., Berger, U., Goss, K. U., and Ulrich, N. (2020) Membrane/Water Partitioning and Permeabilities of Perfluoroalkyl Acids and Four of their Alternatives and the Effects on Toxicokinetic Behavior. Environ. Sci. Technol. 54, 5051-5061.

(7) Henneberger, L., Mühlenbrink, M., Fischer, F. C., and Escher, B. I. (2019) C18-Coated SolidPhase Microextraction Fibers for the Quantification of Partitioning of Organic Acids to Proteins, Lipids, and Cells. Chem. Res. Toxicol. 32, 168 - 178.

(8) Escher, B. I., Glauch, L., Konig, M., Mayer, P., and Schlichting, R. (2019) Baseline Toxicity and Volatility Cutoff in Reporter Gene Assays Used for High-Throughput Screening. Chem. Res. Toxicol. 32, 1646-1655. 